\title{
Kualitas Tepung Ikan di Pesisir Pantai Kabupaten Merauke Sebagai Bahan Pakan
}

\section{Quality of Fish Flour on the Coast of Merauke Regency as Feed}

\author{
Irine I. Praptiwi, Wahida
}

Fakultas Pertanian Universitas Musamus

Jl. Kaizaun Mopah Lama, Merauke, Papua

\author{
Article history \\ Received: Sep 07, 2020; \\ Accepted: Jul 30, 2021 \\ * Corresponding author: \\ E-mail: \\ irineike@gmail.com \\ DOI: \\ 10.46549/jipvet.v11i2.146
}

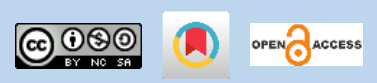

\begin{abstract}
Catch fish that are not used as food can be processed into fish flour. The purpose of this study was to analyze fish meal from several types of fish found on the coast of Merauke Regency. This test is carried out to see the physical and chemical quality. From the research results of this study obtained the physical quality of fish meal can be which is categorized, both in mixing feed food and storage namely: the average density of $0.58 \mathrm{~g} / \mathrm{cm}^{3}$, surface area $53.88 \mathrm{~cm}^{2}, \mathrm{pH}$ 6.25 , threshold power $1.15 \mathrm{~m} / \mathrm{sec}$ and stack angle $27.26^{\circ} \mathrm{C}$, average ash content of $6.31 \%$, protein $65.46 \%$, fat $5.46 \%$, These results indicate the quality of fish meal is included in standard I based on the quality of SNI 2013 as feed material. Types of fish meal that have low economic value and potential to be developed as feed ingredients include Kaca fish (Kurtus gulliveri), Pasir fish (Platycephalus endrachtensis), Bete-Bete fish (Rhinoprenes pentanemus), Duri Herkules fish (Arius sp) and Duri putih fish (Arius leptaspis).
\end{abstract}

Keywords: Fish flour, Quality, Physical, Chemical

Abstrak
Ikan hasil tangkapan yang tidak dimanfaatkan sebagai pangan, dapat diolah
menjadi tepung ikan. Tujuan dari penelitian ini adalah menganalisis tepung ikan
dari beberapa jenis ikan yang ditemukan di pesisir pantai, merupakan hasil
tangkapan nelayan, pengujian berupa kualitas fisik dan kimia. Metode yang
digunakan metode observasi. Dari hasil penelitian diperoleh kualitas fisik tepung
ikan dikatagorikan baik dalam pencampuran pakan dan penyimpanan, nilai berat
jenis rata-rata $0,58 \mathrm{~g} / \mathrm{cm}^{3}$, luas permukaan $53,88 \mathrm{~cm}^{2}, \mathrm{pH} 6,25$, daya ambang 1,15
m/dtk dan sudut tumpukan $27,26^{\circ} \mathrm{C}$. Rata-rata kandungan abu $6,31 \%$, protein
$65,46 \%$, lemak $5,46 \%$, hasil ini menunjukkan kualitas tepung ikan masuk dalam
standar I berdasarkan mutu SNI 2013 sebagai bahan pakan. Hasil buangan dari
tangkapan dan potenisial untuk dikembangkan sebagai bahan pakan meliputi Ikan
Kaca (Kurtus gulliveri), Ikan Pasir (Platycephalus endrachtensis), Ikan Bete-Bete
(Rhinoprenes pentanemus), Ikan Duri Herkules (Arius sp) dan Ikan Duri putih
(Arius leptaspis).

Kata kunci: Tepung ikan, Kualitas, Fisik, Kimia

\section{PENDAHULUAN}

Ketersediaan tepung ikan sangat dibutuhkan untuk pemenuhan nutrisi. Selain sebagai sumber protein, terpung ikan merupakan elemen terpenting dari makanan ternak khususnya unggas yang dibutuhkan untuk merangsang pertumbuhan daging dan produksi telur. Nutrisi tepung ikan berturut- 
turut Protein Kasar 47,85\%; Serat Kasar 1,49\%; kandungan Lemak 8,09\%; dan BETN 3,08\%; serta Energi Bruto 3.730,14 kal/gr (Alamsyah, 2005). Tepung ikan juga disebut sebagai unidentified growth factor (UGF) yang sulit digantikan oleh bahan lain, khususnya untuk pakan ternak. Sebagai bahan pakan, ketersediaan tepung ikan masih terbatas, apalagi di Kabupaten Merauke belum ada yang memproduksi tepung ikan. Disisi lain Kabupaten Merauke dikelilingi oleh pesisir pantai, hal ini mendukung ketersediaan ikan cukup melimpah, baik untuk di konsumsi masyarakat maupun yang tidak dikonsumsi sehingga menjadikannhya memiliki nilai ekonomis rendah.

Hasil tangkapan ikan yang tidak dimanfaatkan sebagai bahan pangan bernilai ekonomis rendah dapat diolah menjadi tepung ikan sebagai bahan baku pakan sumber protein, sejauh ini pembuatan tepung ikan dari hasil tangkapan yang tidak dimanfaatkan di Kabupaten Merauke belum dilakukan. Oleh karena itu, sebelem pembuatan tepung ikan, maka diperlukan kajian terhadap kualitas, baik fisik maupun kimia untuk memproduksi tepung ikan yang ada di pesisir pantai Kabupaten Merauke.

Pengujian secara fisik dan kimia, merupakan pengujian dasar yang dapat dilakukan untuk menentukan kualitas bahan pakan. Pengujian fisik meliputi pengujian $\mathrm{pH}$, berat jenis, daya ambang, sudut tumpukan, sedangkan pengujian kimia meliputi kadar air, abu, protein, lemak dan serat kasar. Hasil yang diperoleh akan menjadi dasar dalam penyusunan ransum, terutama ransum yang membutuhkan kandungan protein yang berasal dari protein hewani berupa tepung ikan. Pemanfaatan lebih jauh sebagai bahan pakan sumber protein, perlu dikaji kualitasnya baik fisik maupun kimia, sehingga menjadi acuan dalam pengolahan tepung ikan dan pakan. Jenis tepung ikan yang berbeda maka kualitasnya juga berbeda. Hasil penelitian Wahyu \& Assadad (2016) bahwa bahan baku dan metode yang berbeda dalam pembuatan tepung ikan menyebabkan berbeda kualitas tepung ikannya.

Tujuan dari penelitian ini untuk menganalisis kualitas fisik dan kimia tepung ikan yang ditemukan di pesisir Kabupaten
Merauke dan membandingkan dengan standar SNI untuk dijadikan sebagai bahan pakan.

\section{MATERI DAN METODE}

\section{WAKTU DAN TEMPAT}

Penelitian dilaksanakan dari bulan September hingga Desember 2019 pada Laboratorium Peternakan Universitas Musamus Merauke untuk pembuatan tepung ikan dan pengujian fisik sedangkan laboratorium PAU Institut Pertanian Bogor untuk pengujian kimia.

Materi yang digunakan berupa beberapa jenis ikan hasil tangkapan nelayan di pesisir Kabupaten Merauke seperti ikan tulang (Hilsa $s p$ ), ikan sumpit (Toxotes sp), ikan duri herkules (Arius sp), ikan mata bulan (Megalops sp), ikan duri putih (Arius leptaspis), ikan air (Harpadon microchip), ikan pasir (Platycephalus endrachtensis), ikan bulanak (Rhinomugil corsula), ikan kuro (Eleutheronema tetradactylum), ikan kaca (Kurtus gulliveri), ikan bête-bete (Rhinoprenes pentanemus), ikan kakap (Lates calcaliver), ikan buntal (Marilyna meraukensis), ikan Mujair (Oreochromis mossambicus), ikan julung - julung (Strongylura strongylura), perangkat alat dan bahan untuk pengujian kualitas fisik dan kimia di Laboratorium. Parameter yang diamati meliputi kualitas fisik berupa $\mathrm{pH}$ pada tepung ikan yang dihasilkan, daya ambang, sudut tumpukan, luas permukaan, serta berat jenis tepung ikan, sedangkan kualitas kimia meliputi kadar air, kadar abu, kadar lemak, kadar protein dan serat kasar.

\section{PROSEDUR PENELITIAN}

Penelitian diawali dengan mengadakan Survei di pesisir pantai Lampu Satu, pesisir pantai Payum, dan 2 titik di kali Maro. Tahap berikutnya berupa pengumpulan ikan-ikan hasil tangkapan yang diperoleh nelayan yang tidak memiliki nilai ekonomis dan kurang diminati oleh masyarakat. Ikan yang telah dikumpulkan disortir berdasarkan jenisnya, masing - masing jenis ikan dibagi 2, untuk pengujian fisik dan pengujian kimia. Tiap jenis ikan diolah menjadi tepung dengan metode pengukusan dan pengeringan, masing - masing jenis ikan dikukus selama 5 menit, kemudian ikan tersebut disaring mengunakan kain, hasil saringan dikeringkan menggunakan oven 
dengan suhu $70^{\circ} \mathrm{C}$ selama 24 jam, setelah kering dihaluskan menggunakan blender sehingga menjadi tepung. Sampel yang telah menjadi tepung dilanjutkan dengan pengujian fisik dan kimia. Pengujian fisik berupa $\mathrm{pH}$ menggunakan $\mathrm{pH}$ meter, pengukuran daya ambang dengan cara menjatuhkan sampel tepung ikan sebanyak 1 gr pada ketinggian $1 \mathrm{~m}$, kemudian mencatat waktu tempuh hingga jatuh. Pengukuran sudut tumpukan dengan cara menuang sample sebanyak 200gr melalui corong pada besi penyangga, diameter dan tinggi curahan sample diukur. Luas permukaan diperoleh dengan cara menimbang sampel sebanyak 1gr, meratakannya pada kertas millimeter blok dan mengukur luas permukaan sampel. Yang terakhir pengukuran berat jenis dengan cara menimbang gelas ukur kemudian memasukkan sampel ke dalam gelas ukur hingga volume $100 \mathrm{ml}$ dan menimbang gelas beserta sampel. Pengujian kimia dengan mengirimkan sebagian sampel ke laboratorium PAU IPB.

\section{METODE}

Metode dalam penelitian ini adalah metode observasi, dilanjutkan dengan tabulasi data yang diperoleh. Data yang diperoleh dianalisis secara statistik deskriptif.

\section{HASIL DAN PEMBAHASAN}

\section{JENIS IKAN}

Berdasarkan hasil survey yang dilakukan ditemukan 15 jenis ikan yang ada di lokasi penangkapan ikan yaitu di pesisir pantai Lampu Satu, pesisir pantai Payum, dan 2 titik di kali Maro. Jenis ikan yang diperoleh relatif sama dengan ikan yang diperoleh di lautan karena intrusi air laut jauh hingga kepala kali. 15 jenis ikan yang ditemukan itu meliputi : ikan tulang (Hilsa sp), ikan sumpit (Toxotes sp), ikan duri herkules (Arius sp), ikan mata bulan (Megalops $s p$ ), ikan duri putih (Arius leptaspis), ikan air (Harpadon microchip), ikan pasir (Platycephalus endrachtensis), ikan bulanak (Rhinomugil corsula), ikan kuro (Eleutheronema tetradactylum), ikan kaca
(Kurtus gulliveri), ikan bête-bete (Rhinoprenes pentanemus), ikan kakap (Lates calcaliver), ikan buntal (Marilyna meraukensis), ikan Mujair (Oreochromis mossambicus), ikan julung-julung (Strongylura strongylura). Beberapa jenis ikan yang ditemukan pada bulan September ini didukung oleh penelitian Sisca et al. (2019); Maturbongs et al. (2019); Sunarni dan Modesta (2018). Dari 15 jenis ikan ini tidak seluruhnya mempunyai potensi untuk dikembangkan sebagai bahan baku pakan, hal ini karena bahan pakan yang digunakan sebaiknya tidak bersaing dengan manusia dan jumlahnya banyak serta tersedia sepanjang musim.

Pemilihan bahan baku pakan harus memenuhi ketentuan tidak bersaing dengan kebutuhan manusia dan tersedia dalam jumlah yang cukup, hal ini sesuai dengan pendapat (Subekti, 2009), sumber pakan yang baik adalah yang mempunyai potensi yang tinggi dan kontinyu, mudah tersedia dan tidak bersaing dengan manusia. Ditambahkan oleh (Siti \& Retno, 2017), beberapa hal yang harus diperhatikan dalam penyusunan pakan berkualitas adalah bahan pakan mengandung zat gizi yang dibutuhkan ternak, mudah diperoleh, terjamin ketersediannya sepanjang waktu, disukai ternak, harga bahan pakan terjangkau, bahan pakan tidak bersaing dengan kebutuhan manusia, dan tidak mengandung racun atau tidak dipalsukan. Ikan yang berpotensi dikembangkan sebagai tepung ikan untuk bahan baku pakan di pesisir pantai Kabupaten Merauke adalah Ikan Kaca (Kurtus gulliveri), Ikan Pasir (Platycephalus endrachtensis), Ikan Bete-Bete (Rhinoprenes pentanemus), Ikan Duri Herkules (Arius sp), dan Ikan Duri putih (Arius leptaspis).

\section{KUALITAS FISIK}

Kualitas fisik bahan pakan akan mempengaruhi kualitas pakan/ransum. Kualitas fisik yang diuji pada penelitian ini meliputi Berat Jenis (BJ), pH, Luas Permukaan, Daya Ambang dan Sudut Tumpukan. Berdasarkan uji fisik diperoleh kualitas tepung ikan terlihat pada Gambar 1. 


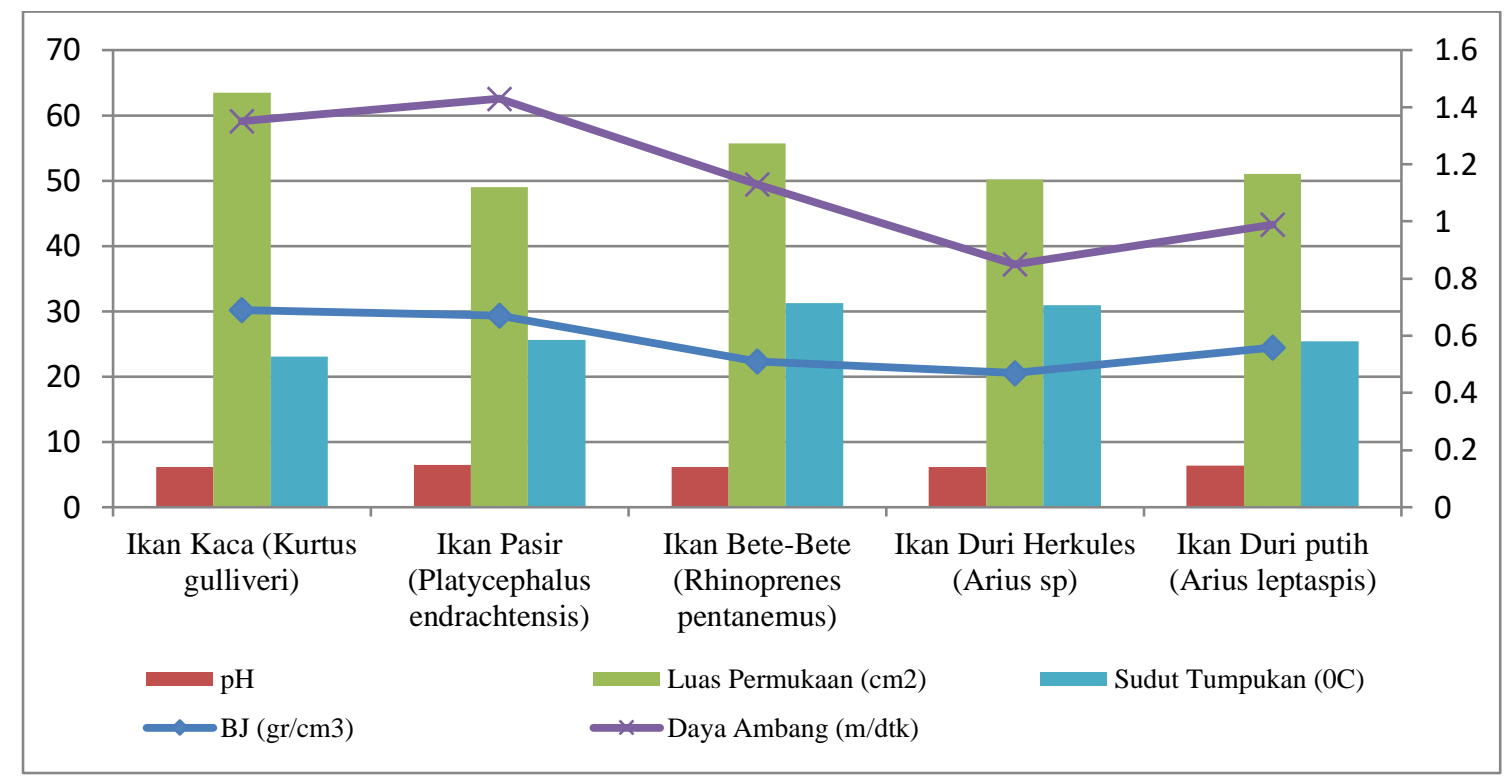

Gambar 1. Grafik kualitas fisik tepung ikan

\section{BERAT JENIS (BJ)}

Berdasarkan uji deskriptif diperoleh ratarata BJ ikan yang ditemukan di pesisir Kabupaten Merauke adalah 0,58 gr/ml, sedangkan untuk nilai BJ tertinggi ada pada jenis ikan kaca (Kurtus gulliveri) sebesar 0,69 $\mathrm{gr} / \mathrm{ml}$ dan terendah pada jenis ikan duri Herkules (Arius sp) sebesar 0,47 gr/ml. BJ bahan pakan akan berpengaruh terhadap proses pencampuran pakan, semakin kecil berat jenis bahan pakan maka pencampurannya akan lebih stabil dan kompak. Hal ini sesuai dengan Retnari et al. (2011), BJ memegang peranan penting dalam berbagai proses pengolahan, penanganan, dan penyimpanan. Pakan atau ransum yang terdiri atas partikel yang berbeda BJnya cukup besar maka campuran ini tidak stabil dan cenderung mudah terpisah kembali. Hal ini didukung oleh Salam (2017) yang menyatakan bahwa pencampuran bahan pakan dengan BJ yang berbeda besarnya membuat partikel bahan tidak dapat saling mengikat dengan baik sehingga antara partikel bahan mudah terpisah antara partikel bahan satu dengan yang lainya.

$\mathrm{PH}$

Nilai $\mathrm{pH}$ tepung ikan tertinggi terdapat pada Ikan Pasir (Platycephalus endrachtensis) sebesar 6,44 dan terendah pada Ikan Bete-Bete (Rhinoprenes pentanemus). Nilai (awal kalimat huruf besar) standar deviasi diperoleh 0,14 menunjukkan bahwa rata-rata nilai $\mathrm{pH}$ pada 5 jenis tepung ikan adalah sama, sebesar 6,25. Nilai pH menunjukkan bahwa tepung ikan yang dihasilkan bersifat netral. Nilai $\mathrm{pH}$ bahan pangan selama penyimpanan dapat berubah karena adanya protein yang terurai oleh enzim proteolitik dan bantuan bakteri menjadi asam karboksilat, asam sulfida, amoniak dan jenis asam lainnya (Bawinto et al., 2015).

\section{LUAS PEMUKAAN}

Berdasarkan hasil penelitian diperoleh rata-rata luas permukaan $53,88 \mathrm{~mm}^{3}$, sedangkan nilai tertinggi ditemukan pada jenis ikan Kaca (Kurtus gulliveri) dengan nilai $63,50 \mathrm{~mm}^{3}$ dan nilai terendah ditemukan pada jenis Ikan Pasir (Platycephalus endrachtensis) dengan nilai $49,00 \mathrm{~mm}^{3}$. Rata-rata luas permukaan 53,88 $\mathrm{mm}^{3}$. Luas permukaan berhubungan dengan metode penyimpanan, semakin luas permukaan semakin besar daya serap, sehingga diperlukan wadah dan kondisi penyimpanan yang sesuai agar tidak mudah terpengaruh dengan kondisi luar. Menurut Nurani et al. (2013), semakin luas permukaan partikel, maka semakin banyak kemungkinan air yang dapat diserap. Luas permukaan juga berhubungan dalam pencampuran, semakin luas permukaan semakin mempermudah dalam pencampuran dengan bahan lain dalam pembuatan pakan. Ukuran partikel berhubungan dengan luas permukaan dan mempengaruhi sifat fisika, misalnya kelarutan dan tingkat homogenitas, 
luas permukaan yang besar mempercepat kelarutan dan homogenitas (Sinila, 2016).

\section{DAYA AMBANG}

Daya ambang adalah jarak yang ditempuh oleh suatu partikel bahan jika dijatuhkan dari atas ke bawah selama jangka waktu tertentu (m/detik). Daya ambang bahan dikatakan besar jika semakin pendek jarak jatuh yang dicapai per satuan waktu (Syamsu, 2007). Hasil penelitian menunjukkan rata-rata daya ambang $1,15 \mathrm{~m} /$ detik dengan standar deviasi diperoleh 0,24 . Nilai tertinggi diperoleh sebesar 1,43 $\mathrm{m} /$ detik yaitu pada jenis ikan Pasir (Platycephalus endrachtensis), dan terendah sebesar 0,85 m/detik yaitu pada jenis Ikan Duri Herkules (Arius $s p$ ).

\section{SUDUT TUMPUKAN}

Sudut tumpukan merupakan sudut yang terbentuk antara bidang datar dengan kemiringan tumpukan ketika bahan dicurahkan dari ketinggian tertentu ke bidang datar. Bentuk cair, sudut tumpukan $0^{\circ}$; bahan sangat mudah mengalir $20-30^{\circ}$, mudah mengalir $30-38^{\circ}$, medium/sedang $38-45^{\circ}$, sulit mengalir $45-55^{\circ}$.

Berdasarkan hasil penelitian diperoleh hasil rata - rata sudut tumpukan $27,26^{\circ}$, dengan standar deviasi $3,68^{\circ}$, nilai maksimum sebesar $31,30^{\circ}$ pada jenis ikan Bete-Bete (Rhinoprenes pentanemus), sedangkan nilai minimum $23,03^{\circ}$ pada kan Kaca (Kurtus gulliveri).

Besarnya sudut tumpukan sangat dipengaruhi oleh ukuran, bentuk, dan karakteristik partikel, kandungan air, berat jenis, dan kerapatan tumpukan, ukuran partikel mempengaruhi sudut tumpukan, yaitu semakin kecil ukuran partikel maka semakin tinggi sudut tumpukannya. peningkatan kadar air menyebabkan penurunan nilai kerapatan tumpukan. Bahan yang sangat mudah mengalir memiliki sudut tumpukan berkisar antara 20-30 (Retnani et al., 2009).

Tepung ikan hasil penelitian masuk dalam katagori mudah mengalir, hal ini berpengaruh terhadap proses pencampuran menjadi pakan nantinya, dan akan perpengaruh juga terhadap proses pengisian serta pengosongan silo apabila di gunakan pada skala industry. Bahan yang mempunyai sudut tumpukan lebih dari $29^{\circ}$ termasuk bahan yang mudah diangkut dengan alat mekanik. Sudut tumpukan akan mempengaruhi flowability atau daya alir suatu bahan terutama akan berpengaruh terhadap kecepatan dan efisiensi proses pengosongan silo secara vertikal pada saat pemindahan dan pencampuran bahan (Retnani et al., 2010).

\section{KUALITAS KIMIA}

Zat gizi yang terkandung dalam tepung ikan khususnya protein akan menentukan kualitas dari tepung ikan yang dihasilkan. Uji kualitas kimia yang dilakukan untuk mengetahui kualitas tepung ikan pada penelitian ini meliputi kadar air (KA), bahan kering (BK), Abu, Lemak, Protein, dan Serat Kasar. Hasil dari analisis kimia ditunjukkan pada Gambar 2.

$A B U$

Kadar abu menunjukkan besarnya jumlah mineral yang terkandung dalam bahan pangan tersebut (Orlan et al., 2019). Berdasarkan hasil penelitian diperoleh rata-rata kadar abu $6,00 \%$, dengan nilai tertinggi $8,87 \%$ pada jenis ikan Kaca (Kurtus gulliveri) dan terendah sebesar 3,41\% pada jenis ikan Duri Herkules (Arius sp). Standar deviasi menunjukkan nilai 2,04 yang berarti kadar abu pada 8 jenis ikan yang ditemukan tidak seragam, perbedaan ini dapat disebabkan karena kandungan mineral yang ada pada tiap jenis ikan berbeda-beda, ada jenis ikan yang memiliki kandungan duri lebih banyak dan ada yang didominasi daging, seperti pada ikan Kaca (Kurtus gulliveri), kandungan duri yang bersifat halus yang dimiliki cukup banyak, saat proses pembuatan tepung ikan ini tidak dipisahkan antara duri yang halus dengan dagingnya, melainkan dilakukan pengeringan dan pencampuran bersamaan, kecuali duri yang keras yang berada pada bagian tengah ikan yang tidak digunakan. Tulang halus ini juga berfungsi sebagai sumber mineral.

Pengolahan tepung ikan melalui proses pengeringan dalam waktu yang cukup selama 24 jam dengan suhu $70^{\circ} \mathrm{C}$. Proses ini juga mempengaruhi kadar abu. Hal ini sesuai dengan pendapat (Wahyu \& Assadad, 2016), kadar abu dikenal sebagai unsur mineral atau zat anorganik. Mineral merupakan salah satu komponen dalam bahan makanan. Kadar abu pada tepung ikan dipengaruhi oleh bahan baku yang digunakan dan proses pengolahannya. Bahan yang diolah melalui proses pengeringan 
akan meningkatkan kadar abu bila suhunya semakin tinggi karena air yang keluar dari dalam bahan semakin besar.

Jika dilihat berdasarkan standar SNI yang ditentukan, maka kadar abu pada 5 jenis tepung ikan ini masih di bawah $20 \%$ dengan rata-rata $6,31 \%$, hal ini menunjukkan bahwa kadar abu pada tepung ikan hasil penelitian berada pada standar I.

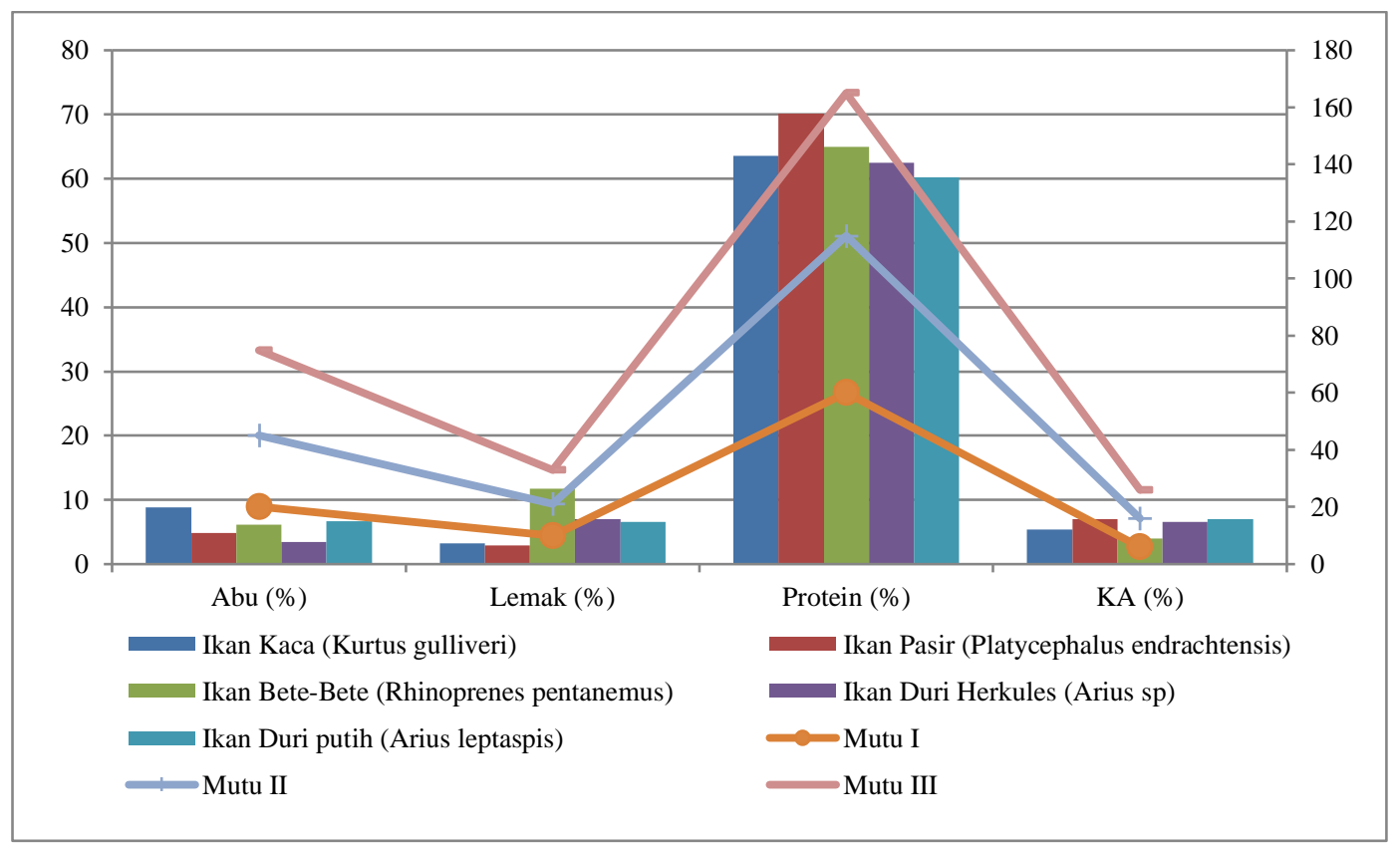

Gambar 2. Kualitas kimia tepung ikan

\section{PROTEIN}

Tepung ikan sebagai sumber protein hewani memiliki kedudukan penting yang sampai saat ini masih sulit digantikan kedudukannya oleh bahan baku lain bila ditinjau dari kualitas. Kandungan protein tepung ikan memang relatif tinggi. Protein tersebut disusun oleh asam-asam amino esensial yang kompleks (Wahyu \& Assadad, 2016).

Hasil analisis diperoleh rata-rata kandungan protein pada 5 jenis tepung ikan adalah $64,27 \%$, dengan kandungan tertinggi pada ikan Pasir (Platycephalus endrachtensis) yaitu $70,14 \%$, dan terendah pada jen is ikan Duri Putih (Arius leptaspis), yaitu 60,74\%. Kandungan protein pada 5 jenis tepung ikan yang berasal dari Kabupaten Merauke ini cukup tinggi, sesuai dengan standar SNI.

Ransum khususnya untuk pakan unggas, dibutuhkan protein karena dalam protein terkandung beberapa asam aminonya. Faktor yang menentukan kualitas pakan adalah kandungan protein yang ada pada pakan tersebut, kandungan protein ini terntunya berasal dari bahan baku sumber protein.
Berdasarkan hasil penelitian Nunik et al. (2017) bahwa dalam pemeliharaan ayam lokal persilangan yang diberi, 2 sumber protein yaitu bungkil kedelai dan tepung ikan lebih efisien dibandingkan dengan bahan pakan, sumber protein lain. Hal yang serupa juga pada penelitian Utomo et al. (2013) bahwa penggunaan tepung ikan rucah menghasilkan pertumbuhan terbaik pada ikan lele sangkuriang, selain sebagai sumber protein atau asam amino, tepung ikan juga merupakan sumber asam lemak yang berkualitas baik (Marjuki, 2008).

\section{LEMAK}

Lemak dalam ransum ternak digunakan terutama untuk sumber energi ransum dan meningkatkan palatabilitas, juga untuk membantu mengurangi berdebunya ransum dan mencegah pemisahan bahan makanan. (Sihite, 2013).

Berdasarkan hasil penelitian diketahui rata-rata kandungan lemak pada 5 jenis tepung ikan asal pesisir Kabupaten Merauke ini adalah $6,30 \%$. Kandungan tertinggi pada jenis ikan Bete-Bete (Rhinoprenes pentanemus), dengan nilai $11,71 \%$, sedangkan terendah pada jenis 
ikan Pasir (Platycephalus endrachtensis) dengan nilai $2,93 \%$. Sesuai dengan standar SNI batas maksimum kadar lemak pada tepung ikan pada standar I adalah $10 \%$ dan mutu II adalah $11 \%$, untuk rata-rata kandungan lemak pada tepung ikan hasil penelitian masih masuk pada katagori standar I dengan standar deviasi 3,01, sehingga hanya jenis ikan Bete-Bete (Rhinoprenes pentanemus) yang masuk katagori standar II sedangkan yang lainnya masuk katagori standar I.

Kadar lemak sangat mempengaruhi kualitas tepung ikan, tepung ikan yang baik memiliki kadar lemak maksimal sebesar $12 \%$, Kadar lemak yang tinggi juga akan mempercepat terjadinya ketengikan pada tepung (Wahyu \& Assadad, 2016). Hal serupa disampaikan Orlan et al. (2019), bahwa kadar lemak yang tinggi mengakibatkan tepung cepat tengik atau mudah mengalami oksidasi lemak. Kadar lemak yang rendah membuat mutu relatif lebih stabil dan tidak mudah rusak.

\section{SERAT KASAR}

Hasil penelitian menunjukkan kandungan serat kasar pada 5 jenis tepung ikan yang diperoleh adalah 0 , kebutuhan serat kasar dapat diperoleh dari bahan pakan lainnya dalam penyusun ransum, karena ransum merupakan campuran dari berbagai macam bahan pakan untuk memenuhi kebutuhan hidup ternak selama 24 jam. Kandungan serat kasar yang tinggi menyebabkan kesulitan ternak dalam mencerna pakan, terutama pada nonruminsia.

Serat kasar berfungsi untuk merangsang gerak peristaltik saluran pencernaan, sebagai media mikroba pada usus buntu yang akan menghasilkan vitamin $\mathrm{K}$ dan B12, serta untuk memberikan rasa kenyang. Penggunaan maksimum serat kasar dalam bahan baku pakan tidak lebih dari 5\% (Sihite, 2013).

\section{KADAR AIR (KA)}

Kadar air yang diperoleh menunjukkan rata-rata $6,00 \%$, dengan kandungan tertinggi terdapat pada jenis ikan Pasir (Platycephalus endrachtensis) dengan nilai 7,04\%; dan terendah pada jenis Bete-Bete (Rhinoprenes pentanemus) dengan nilai $4,03 \%$. Berdasarkan standar SNI katagori satandar I dengan kandungan kadar air $6-10 \%$ dan standar II dengan kandungan kadar air $10-12 \%$. Hal ini menunjukkan rata-rata kandungan kadar air pada 5 jenis tepung ikan yang ditemukan masih berada pada standar I, jenis ikan dengan kandungan tertinggi juga masih berada pada standar I walaupun $>6 \%$. Jika kadar air tepung ikan lebih dari $10 \%$ maka akan menurunkan mutu tepung ikan karena dapat meningkatkan aktivitas mikroorganisme khususnya bakteri Salmonella (Orlan, 2019).

Walaupun kandungan air berada pada standar I namun nantinnya perlu memperhatikan proses penyimpanan tepung ikan ini, karena akan berpengaruh terhadap kadar air. Semakin lama penyimpanan, maka akan meningkatkan kadar air bahan. Perubahan kadar air dapat disebabkan pengaruh suhu dan kelembaban selama penyimpanan, bila kelembaban udara ruang penyimpanan tinggi maka akan terjadi absorpsi uap air dari udara ke ransum yang menyebabkan kadar air ransum meningkat (Retnani et al., 2009). Hal serupa juga dikemukakan oleh Orlan et al. (2019), semakin lama penyimpanan, menyebabkan kadar air semakin meningkat.

\section{KESIMPULAN}

Dari hasil penelitian dapat disimpulkan, Kabupaten Merauke memilki potensi dalam penyediaan tepung ikan sebagai bahan baku pembuatan pakan. Tepung ikan yang memiliki nilai ekonomis rendah dan potensial untuk dikembangkan sebagai bahan pakan meliputi Ikan Kaca (Kurtus Gulliver), Ikan Pasir (Platycephalus endrachtensis), Ikan Bete-Bete (Rhinoprenes pentanemus), Ikan Duri Herkules (Arius sp), dan Ikan Duri putih (Arius leptaspis). Berdasarkan uji kualitas fisik, proses pembuatan tepung ikan malalui perebusan dan pengeringan mengasilkan bahan baku yang baik dalam pencampuran pakan dan penyimpanan bahan baku. Standar deviasi untuk kualitas fisik tepung ikan menunjukkan keseragaman dilihat dari berat jenis, $\mathrm{pH}$, sudut tumpukan, daya ambang dan luas permukaan. Kualitas kimia rata-rata kandungan abu sebasar $6,00 \%$, kandungan protein $64,27 \%$, kandungan lemak $6,30 \%$, kandungan serat kasar 0 dan kandungan kadar air rata-rata 6,00\%. Kualitas kimia yang meliputi kadar air, protein, lemak, serat kasar dan kadar abu, tepung ikan dari 5 jenis ikan yang ditemukan di pesisir pantai 
Kabupaten Merauke masuk katagori standar I berdasarkan mutu SNI 2013.

\section{DAFTAR PUSTAKA}

Alamsyah R. 2005. Pengolahan Pakan Ayam dan Ikan Secara Modern. Jakarta: Penebar Swadaya.

Bawinto AS, Mongi E dan Kaseger BE. 2015. Analisa Kadar Air, Ph, Organoleptik, Dan Kapang Pada Produk Ikan Tuna (Thunnus Sp) Asap, Di Kelurahan Girian Bawah, Kota Bitung, Sulawesi Utara. Jurnal Media Teknologi Hasil Perikanan. Vol. 3, No. 2, Agustus 2015.

Elviana S, Modesta RM, Sunarni, Chair R dan Andi IB. 2019. Keragaman jenis ikan di Sungai Maro pada musim peralihan I . Jurnal Ilmu-Ilmu Perairan, Pesisir dan Perikanan , 97 - 107.

Marjuki. 2008. Penggunaan Tepung Ikan dalam Pakan Konsentrat dan Pengaruhnya Terhadap Pertambahan Bobot Badan Kambing Betina. Ternak Tropika, 9(2), 90 $-100$.

Maturbongs MR, Sisca E, Rani C dan Andi BI. 2019. Keterkaitan Parameter Fisik-Kimia Perairan dengan Kelimpahan Jenis Ikan Demersal di Sungai Maro pada Fase Bulan Berbeda Musim Peralihan I. AGRIKAN Jurnal Agribisnis Perikanan, 162 - 173.

Nunik IV, Umiyati A dan Luthfi DM. 2017. Pengaruh Pemberian Pakan dengan Sumber Protein Berbeda terhadap Efisiensi Penggunaan Protein Ayam Lokal Persilangan . Agripet Vol 17, No. 1, 53 - 59.

Nurani D, Irianto H dan Hapsari H. 2013. Kajian Tingkat Peyerapan Minyak Goreng oleh Tepung Penyalut Kacang Keriting. Prosiding Seminar Nasional PATPI Jember, 26 - 29 Agustus 2013.

Orlan, Asminaya NS dan Nasiu F. 2019. Karakteristik Fisiko Kimia Tepung Ikan yang Diberi Pengawet Bawang Putih (Allium sativum) pada Masa Penyimpanan yang Berbeda . Jurnal Agripet Vol 19, No. 1 .

Retnani Y, Hasanah N, Rahmayeni dan Herawati L. 2010. Uji Sifat Fisik Ransum Ayam Broiler Bentuk Pellet yang Ditambahkan Perekat Onggok Melalui
Proses Penyemprotan Air. Agripet Vol 10, No. 1.

Retnani Y, Wigati D dan Hasjmy AD. 2009. Pengaruh Jenis Kemasan dan Lama Penyimpanan terhadap Serangan Serangga dan Sifat Fisik Ransum Broiler Starter Berbentuk Crumble. Jurnal Ilmiah IlmuIlmu Peternakan Vo XII, No 3.

Retnari Y, Herawati L dan Khusniati S. 2011. Uji Sifat Fisik Ransum Broiler Starter Bentuk Crumble Berperekat Tepung Tapioka, Bentonit Dan Onggok. JITP Vol. 1 No. 2.

Salam, Rivai dan Mutfi. 2017. Sifat Fisik Wafer dari Bahan Baku Lokal sebagai Bahan Pakan Ternak Ruminansia. Jurnal Ilmiah Peternakan Vol 5 No 2. 108 - 114.

Sihite H. 2013. Studi Pemanfaatan Limbah Ikan dan Tepung Pelelangan Ikan dan Pasar Tradisional Nauli Sibolga Menjadi Tepung Ikan. Teknologi Kimia Unimal43 - 54, 2(2).

Sinila S. 2016. Farmasi Fisik. Modul Bahan Ajar Cetak Farmasi. Kementrian Kesehatan Republik Indonesia. Pusat Pendidikan Sumber Daya Manusia Kesehatan. Badan Pengembangan dan Pemberdayaan Sumber Daya manusia Kesehatan.

Siti E dan Retno SW. 2017. Teknologi Complete Feed Herbal Untuk Peningkatan Produktivitas Sapi Potong Di Kecamatan Parengan Kabupaten Tuban. Agroveteriner Vol 6 No 1.

Subekti E. 2009. Ketahanan Pakan Ternak Indonesia. Mediagro VOL 5. NO 2, 63-71.

Sunarni dan Modesta R. 2018. Komposisi dan kelimpahan jenis ikan di Pesisir Pantai Payumb, Kota Merauke . Jurnal Akuakultur, Pesisir dan Pulau-Pulau Kecil, 5 - 9 .

Utomo NB, Priyo S dan Setiawati M. 2013. Peran tepung ikan dari berbagai bahan baku terhadap pertumbuhan lele sangkuriang Clarias sp. . Jurnal Akuakultur Indonesia 12 (2), 158-168.

Wahyu TH dan Assadad L. 2016. Karakterisasi Proses Produksi dan Kualitas Tepung Ikan di Beberapa Pengolah Skala Kecil. Seminar Nasional Tahunan XIII Hasil Penelitian Perikanan dan Kelautan, (pp. 197 - 205). Yogyakarta. 